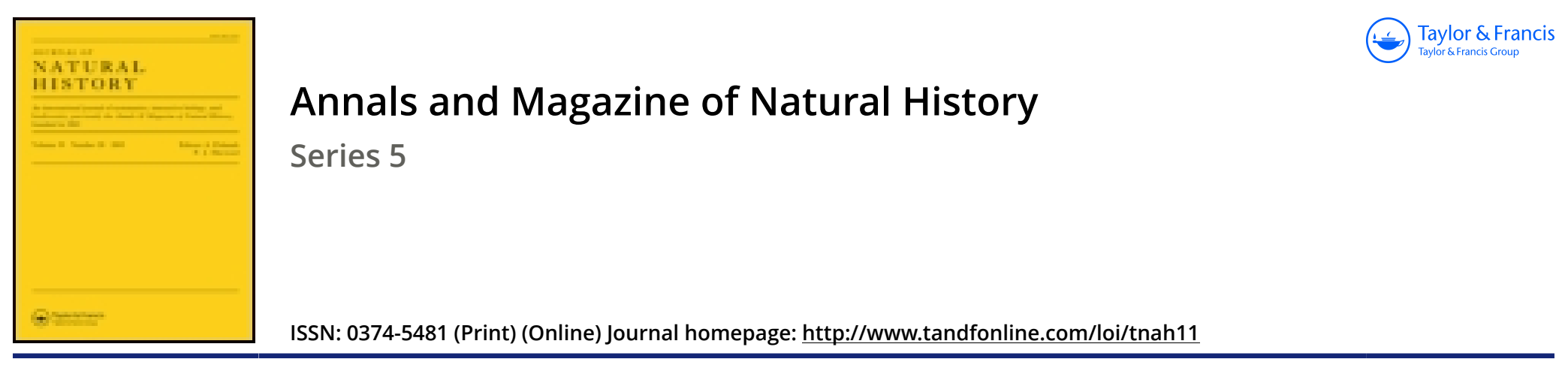

\title{
VIII.-Remarks on Dr. Hamann's researches in the morphology of the Echinoidea
}

\section{Prof. P. Martin Duncan F.R.S.}

To cite this article: Prof. P. Martin Duncan F.R.S. (1886) VIII.-Remarks on Dr. Hamann's researches in the morphology of the Echinoidea, Annals and Magazine of Natural History, 18:103, 66-69, DOI: $10.1080 / 00222938609459933$

To link to this article: http://dx.doi.org/10.1080/00222938609459933

$$
\text { 盟 Published online: } 07 \text { Oct } 2009 .
$$

\section{Submit your article to this journal $\square$}

Џ Article views: 1 
VIII.-Remarks on Dr. Hamann's Researches in the Morphology of the Echinoidea. By Prof. P. Martin Duncan, F.R.S. \&c.

Dr. Hamann was good enough to send me a copy of his very interesting and valuable "Vorläufige Mittheilungen zur Morphologie der Echiniden" ; it arrived whilst I was engaged in the study of the histology of some of the same structures which have been so well described by him, but in another group of genera. I venture to make the following observations on two of the subjects which have especially been considered by Dr. Hamann.

\section{The Globiferen.}

These organs are a discovery of Dr. Hamann's, and, as might have been expected from his former work on the Holothuroidea, they are clearly described and are therefore readily recognized.

But the diagram given by Dr. Hamann of a globifer of Sphorechinus granularis is rather misleading, and the real organs would hardly be recognized therefrom. The three "Drüsenballen" are more united at their common base than the diagram indicates, and the npper ends are more or less constricted and have very large foramina for the exit of the mucus. The three masses are really continuous by their outer coat at their bases and rest upon a shorter stem than that shown in the figure. In fact, owing to the diagram I overlooked these organs in the first instance; and so did a fellow-worker. But when a number of tripartite bodies fixed on short stalks, and which looked like stunted ordinary pedicellariæ globiferæ (=gemmiformes) of Sphorechinus, had been separated from the test and examined, their identity with the organs described by Dr. Hamann and their distinctness from the ordinary pedicellariæ became evident.

There is no glandular enlargement of the shaft in the newly-described structures, and the stem, otherwise like that of a pedicellaria, springs from the test and has the usual soft structures at its origin. The head has three parts united at the base, very tumid inferiorly and slightly roundedly angular at the inner part, and much more rounded above than any

* Sonder-Abdruck aus den Sitzungsberichten der Jenaischen Gesellschaft für Medicin und Naturwissenschaft, Jahrg. 1886; Ann. \& Mag. Nat. Hist. 1886 , vol. xvii. pp. 388,469 . 
pedicellariæ. Presenting the general appearance of one of the pedicellariæ so well described by Sladen (Ann. \& Mag. Nat. Hist. August 1880, p. 101, pls. xii. and xiii.), but without the glands around the long stem, without any calcareous valves within the lobed structures, and without any protrusion of calcareous nature through the large foramen, the simplest examination enables the histological elements described by Dr. Hamann to be seen. As Dr. Hamann has stated, there is the outer epithelial coat, and beneath it connective tissue with C-shaped spicules, with, so far as I could see, but few nerve-fibres, and the close layer of muscular fibres noticed by Dr. Hamann. The mucus-gland layer, with its nucleated cells and granules, is largely developed. In one happy, thin, transverse section the remains of a partition, partly bisecting the mass vertically, was evident. The head of the "organ" obviously consists of three great mucus-glands united at their bases and free above, and the opening is surrounded by a sphineter. It is but just that I should state that, although these special gland-sacs on stems have been discovered and doubtless will be admirably described by Dr. Hamrann, the morphology of the gland-sacs and their coverings was familiar to me, for it is the same as that seen in the pedicellariæ which formed the subject of Sladen's essay, the distinction between the two kinds of organs being of course the presence of the calcareous valves and the tactile cushion and the less globular shape of the pedicellaria, which, moreover, invariably have three glands around the long stem.

In some of the bodies which one would have considered to be Dr. Hamann's organs without doubt, I found exceedingly atrophied calcareous valves in the tumid "Drüsenballen." The valves were very reticulate and delicate in the extreme; but the sharp points and the relics of the curved hasal parts remained. The gland-structure was that described by Dr. Hamann, and there were no tactile cushions to be seen. The foramen was large and had the usual sphincter; there were no glands around the short stem.

I must confess that this finding of an atrophied series of valves, whilst it indicates the direction in which the nature of the new organs should be sought, also diminishes the interest one felt disposed to take in them. It must be remembered that Sladen distinctly states (op. cit. p. 108) that the pedicellariæ globiferæ (= gemmiformes) give forth mucus, and he described their glands. Hence it is correct to state that in function the organs just discovered and the long and valveheaded pedicellaria are partly similar; the latter, being the more highly organized, have a clasping and tactile power, 
besides the ability to excrete mucus, whilst the former are mucus-secretors par excellence.

It appears to me that the organs described by Dr. Hamann are modified pedicellariæ. There appears to be great variation in the morphology of the mucus-secreting organs in the Echinoidea, and whilst the organs described occur in numbers in half grown Sphcerechini, they appear to me to diminish in numbers in larger forms. The name "globiferi" is unfortunate, for so many echinodermatists follow $O$. F. Müller, and term the long-stalked and big-headed pedicellarise $p$. globiferce.

In order to prevent confusion, as the ground is occupied, it would be as well if $\mathrm{Dr}$. Hamann would alter the name of the interesting organs he has discovered.

\section{II. 'The Termination of Nerves in the Echinoidea.}

Having been practically interested in this subject, and having traced the ending of nerve-fibres in the tentacles of some Echinida, it was necessary to recognize the work of former observers. In the midst of my work I had the opportunity of verifying Sladen's statements (op. cit. p. 107, and pl. xiii, fig. 12) and of examining his microscopic preparations. He stated with regard to the tactile cushions on the inner surface of the calcareous valves of the pedicellariæ globiferæ: "These organs, which are finely papillate and richly supplied with nerve-fibres (as will be found indicated in the section in pl. xiii. fig. 12), are presumably of sensorial (i.e. tactile) function, and act as the communicators of the advent of any foreign or irritating elements." The drawing shows, what can be well seen in the thin section, a number of parallel nerve-fibres coming to the surface from out of a layer of nucleated cells. The surface has a very delicate flat epithelium raised here and there into setiform projections. The drawing speaks for itself, and the similarity of the structures represented and those which were descriked and figured some years afterwards by Sven Lovén is remarkable. I have seen the same structure in Coclopleurus Maillardi and cannot consider the drawing otherwise than correct.

Loven, in his wonderful work on the genus Pourtalesia ('Kongl. Svenska Vetenskaps-Akademiens Handlingar,' Bd. xix. no. 7,1883 , pp. 45 to 55 , pl. ix.), described and figured, with his usual great accuracy and art, the terminations of the pedicel-nerves. In fig. 82 the setæ and the expanded nervous structure at the tip of the fibre are distinct, and in figs. $86,87,89$, and 90 the relation of the nerves to the sur- 
face tissue can be well seen. It does not appear to be correct to state that no observers had described or tigured the terminations of nerves in the Echinida before the writer of the interesting little preparatory essay which $[$ have ventured to praise and criticize in a most friendly spirit.

June 1886.

\section{BIBLIOGRAPHICAL NOTICE.}

Memoirs of the Geological Survey of India. Paloontologia Indica, being Figures and Descriptions of the Organic Remains procured during the Progress of the Geological Survey of India. Published by Order of His Excellency the Governor-General of India in Council. Ser. x. Indian Tertiary and Post-Tertiary Vertebrata. Vol.III. Part 6. Siwalik and Narbada Chelonia. By R. LYDEKkER, B.A., F.G.S., \&c. With 10 plates (xviii.-xxvii.). Calcutta : Geological Survey Office. London: Trübner \& Co. 1885.

Is a brinf introduction Mr. Lydekter dwells on the difficulty of dealing with his material, a difficulty which may not be altogether unconnected with the variations of form which the Chelonian carapace often assumes with increasing age in existing species. Many of the Upper-Tertiary tortoises from the Siwaliks prove to be closely allied to species which still inhabit India and adjacent countries, tbough the terrestrial types are specifically distinct from living Indian species. The remains found in the more recent Narbada beds are all referred to existing Indian types.

The descriptions open with an account of additional remains of Colossochelys atlas. Among these the epiplastron is remarkable for its anterior bifureation, a character which serves to distinguish it from the gigantic living tortoises. The xiphiplastron suggests, when taken with the other remains, that the carapace was about 8 feet long, while smaller specimens, which the author regards as probably female, may have been 6 feet long. The carapace, long ago restored by Falconer, shows that the pygal plates, as in the existing Manouria emys, were not united. 'The shaft of the humerus agrees best in proportion with the living Galapagos tortoise, Testudo elephantopus. The fragment indicates a bone 2 feet 4 inches long. A cranium is figured and provisionally referred to this species, which resembles that of Testudo ponderosa of Aldabra in its deeply concave palate, which is narrower than in $T$. elephantina. The head is estimated to have been over 9 inches long. From various resemblances the author is led to the conclusion that the Aldabra tortoises are probably descendants of the old Indian stock. 